\title{
Rasgos e véus
}

Claudia Washington *

Universidade de Brasília

\begin{abstract}
Resumo
O rasgo como ação em arte, as características do espaço onde opera e as decorrências dessa ação são os focos aqui propostos. A partir da prática artística e de referências dessa mesma natureza são estabelecidas interlocuções, contraposições e misturas com textos filosóficos e de arte, em especial com o livro Os cinco sentidos: Filosofia dos corpos misturados 1, de Michel Serres. Este último inspira o teor desta escrita, permeando-a do início ao fim. Nesse percurso é possivel identificar oposições e complementaridades entre os regimes espaciais enredados e o rasgo.
\end{abstract}

\section{Palavras-Chave}

Arte; rasgo; véu; espaço.

\section{Rips and veils}

\section{Abstract}

Rip as an action of art, the characteristics of the space in which it operates and its consequences are the focus here proposed. From artistic practice and references, this article establishes dialogues, contrasts and blends with philosophical and art texts, especially with The Five Senses: Philosophy of mixed bodies 1 of Michel Serres. This book inspired the present writing, permeating it from start to finish. Along the way it is possible to identify oppositions and complementarities between the entangled spatial regimes and the rip.

\section{Keywords}

Art; rip; veil; space.

\footnotetext{
* Doutoranda em Poéticas Contemporâneas pelo ldA - UnB, bolsista Capes, sob orientação de Maria Beatriz de Medeiros. E-mail: claudia@transitos.org. Desde 1996 dedica-se à proposições artísticas entre as artes visuais, performance, dança e teatro. Afeita a processos colaborativos estabeleceu parcerias como nas ações Trânsitos (deslocamentos territoriais e conceituais) e com o Coletivo E/Ou ( descartografias urbanas). Atualmente realiza seus estudos de doutorado na Universidade de Brasília. 
Rasgar. Impingir forças contraditórias ou fricções intencionais e frequentes sobre as coisas pode engendrar vazios no cotidiano encouraçado. Rasgar altera mas não destrói. Não é corte, esgarça as fibras, pode dilacerar caixas, fragilizar e violentar. Rasgar é ação tátil, de contato, é audaz, certeiro, seu tempo indefinível apesar de exato é prática do lugar. O rasgo segue em todas as direções, potencializa a permeabilidade e a transposição de obstáculos. O rasgo é o feito que não se diz só: ele é a borda do rasgado e o vazio, é espaço de liberdade forjado no dia a dia. Por ele é possível sondar, penetrar, varar. Rasgar sem dilacerar é, também, engendrar confusão na superfície lisa das coisas, vazá-la, já que seria impraticável na totalidade das prisões. É não depender das linhas da trama, dos caminhos da rede, desligar do contínuo, desestabilizá-lo. Rasgar, como gesto espacial de separação, produz a condição para que se dê a sensação, o respiro, o conhecimento, ou qualquer outra coisa que careça de espaço para existir. Minha prática artística inclina-se aos espaços rasgáveis e/ou rasgados. Dois de meus trabalhos serão aqui abordados: Trânsito à Margem do Lago (2010/2012) e PLUMBUM! Boca de Mina (em processo). As obras: Ninhos (s. d.), Passagem (1979) e O Muro (1982) de Celeida Tostes, assim como a Experiência $n^{0} 2$ (1931) de Flávio de Carvalho, são importantes referências. Alguns autores que abordam conteúdos alinhados à ideia de rasgo, como as rupturas, fissuras, fendas, falhas, vazios, são aqui comentados, posso citar: Maria Beatriz de Medeiros $^{1}$, Michel Serres, Gilles Deleuze e Anne Cauquelin. Os cinco sentidos: Filosofia dos corpos misturados 1 (2001) de Michel Serres foi a fonte da confusão necessária para poder escrever em arte. Num ir e vir entre ideias divergentes, inconciliáveis, invariantes nas variáveis, 0 autor fechado na linguagem, fechado no livro - esburaca a casca linguística bordeando os seus limites. Ele perpassa as peles, os véus, as dobras, os nós, a bruma, as caixas, o doce e o duro, manifesta nosso estado múmia.

\footnotetext{
1 Em artigo recente, intitulado Bia Medeiros e o tracejo do rasgo, Cinara Barbosa também tratou do rasgo na obra da artista que dá título ao artigo. 
Inspirada no teor ensaístico desenvolvido por Michel Serres, tento uma escrita misturada com as várias outras vozes que aqui ecoam.

A partir disso, busco evidenciar os rasgos como ação e concepção de espaço.

\section{Rasgo, grito, véu, dobra, nó}

Maria Beatriz de Medeiros, em seu livro Aisthesis: estética, educação e comunidades, afirma que arte é comunicação não linguística, voz do corpo e cor do grito (2005: 79), e continua: O grito ao qual nos referimos não diz nada. (...) O grito da arte não grita nada. Ele é sopro escamoteado, voz catastrófica. Ele rasga a totalidade de nosso ser, de nosso corpo. Ele esvazia. Nega, por sua força, a totalidade dos corpos tensos (2005: 80). A autora apresenta, nesta passagem, conformações entre corpo e ato em arte; a condição do primeiro impele a ação radical de rasgar, nesse caso, pelo grito, como sopro que esvazia e fende os corpos tensos. O contexto onde inscreve o grito-rasgo é 0 da linguagem que conforma o espaço esquadrinhado, aprisionante da palavra escrita, falada, pensada. Desde então, uma escrita só pode ser rasgo ao sabor das circunstâncias de arte, pois corpos tensos e estruturas rígidas limitam a experiência. No rastro da autora, posso dizer que, ao buscar as contingências do rasgo, trato de sua existência mundana, como ação. Só consigo tatear suas bordas, de resto é 0 vazio. A arte rasga estruturas rígidas e nesse movimento engendra 0 vazio, do mais sutil toque, brisa macia, chegando às forças dilacerantes do rasgo. A carícia pode ser um princípio corporal de conquista do espaço de si, no campo de encontros que conforma o mundo cariciável. Seria esse o destino da pele?

Pele, limite em abertura. Parece que das placas tectônicas e da pele apreendemos os véus, dobrados sobre eles mesmos, sobre e sob outros, semelhante à tenda, definida pelo fechamento do espaço, fechada (...) faz como que um círculo e volta sobre si (Serres, 2001: 52). A crosta, a 
montanha, e mesmo a bruma nos enfaixa ou nos encouraça (2001: 64). Sabemos apenas a clausura, isolamento, caixa-preta, prisão, trocamos 0 respiro do poro por janelas e portas geometrizantes.

As prisões, variantes dos mais leves véus, desdobram-se: som e palavra dominam o espaço, penetram na pele porosa e vibrante; arquitetura, engenharia, urbanismo - estradas, pontes, cidades, casas, usinas, portos, muros - concretizam limites embrutecidos, delimitam o espaço, definem 0 trânsito dos corpos, domesticam a paisagem; formas sociais, sistema econômico, sistema de comunicação, invólucros históricos (Santos, 2005: 11), modos de produção estabelecem os campos de ação. Jamais desejaremos nada senão a reabertura (Serres, 2001: 53). Também a arte está envolvida por um enclausuramento simbólico, além do enclausuramento físico do in situ (Medeiros, 2005: 103). Essa prisão estabelece os limites do aceitável no mundo e do aceitável em arte, como se fossem dimensões diferentes da existência, quase intocáveis entre si. Certa arte se dedica a atravessar as paredes sólidas dessa construção simbólica e forjar outros graus de liberdade.

Outra prisão pode ser relacionada à rede tautológica que gere as relações do sistema de arte, cujo domínio atual seria mais uma mistura de diversos elementos, dos valores da arte moderna e dos da arte chamada de contemporânea. Tais valores não estariam em conflito aberto mas lado a lado, trocando suas fórmulas, construiriam dispositivos complexos, instáveis, maleáveis, sempre em transformação. Seria impossível traçar precedentes para as rupturas numerosas e falhas profundas que caracterizam a arte contemporânea (Cauquelin, 2005: 131).

Véus e prisões nos envolvem e isso é invariável, o que varia é a intensidade das forças que operam, sua rigidez ou maleabilidade, por exemplo. A noção de variação relacionada aos estudos de Leibniz exige que se pense ao mesmo tempo o estável e o instável, o invariante na variação: ela dá conta 
de uma flexibilidade admissivel para todas as formas, mas ajustável a uma só, única e volúvel, aberta e fechada (Serres, 2001: 63). Descreve o caminho entre valores vizinhos e opostos, miséria e glória, cinza e ouro, do lugar onde o poder nos oprime ao lugar onde ele nos pertence, ou seja, divisão, racional e comum, impulsionada pela violência em nós, que se apresenta em circuito fechado. Mas o caminho de uma dessas posições à outra, mas o continuum que as une ou o fosso que as separa levantam uma questão bem mais temível para a qual não estamos preparados (2001: 61). Que questão é essa? E se esse continuum entre valores extremos fosse pensado como movimento, não de um valor ao outro, mas um movimento de atravessamento, como impulso que rasga os próprios valores, como ação dos corpos frente ao mundo de oposições que conformam o espaço fechado, ferindo-o em oposição a todas as direções? As coisas não estariam necessariamente entre outras duas, mas cravadas atravessariamnas. Fiapos do entre permaneceriam. Os espaços do véu e do rasgo, posso dizer da dobra e do rasgo, se diferenciam:

É talvez no limite que a textura aparece melhor, antes da ruptura ou da dilaceração, quando o estiramento já não se opõe à dobra mas expressaa em estado puro, de acordo com uma figura barroca (...). Também aí a dobra repele a fenda e o buraco; não pertence à mesma visão pictural. (Deleuze, 2000: 69)

Por suas características físicas, o espaço da dobra, dos véus, nega o rasgo. Seriam mundos incompossivveis? Seria o rasgo variação do véu, assim como o remendo? Seria a instabilidade no estável? Para serem incompossíveis necessitamos admitir que rasgo e o véu pertencem a mundos diferentes, mas rasgar só é preciso em um mundo velado, o próprio remendo é compulsório do espaço rasgado. Essa complementaridade não ocorre, por exemplo, em relação à arte e ao conceito, como diz Maria Beatriz de Medeiros: um conceito é a expressão de um mundo possível dentro de um campo perceptível, ainda assim, a arte permanecerá indizível, são mundos incompossiveis (2005: 47). A partir disso é plausível supor que rasgar é um procedimento conveniente à arte para produzir-se indizível num mundo de celas variantes. Rasgar é tátil. É coisa do corpo e do mundo. 
Rasgar subentende o limite, algo entre, que será o objeto do rasgo, desencadeando a partir daí relações antes impossíveis. Se o possível esteve relacionado algum dia à capacidade de algo ser pensado por Deus, e o mundo das coisas, ao visível, à ciência da visão², o impossível acarretaria 0 não pensado e 0 não visto, ambos, materiais da arte. $A$ estética prova o improvável (Serres, 2001: 226).

Se os véus podem ser rasgados, nem todo véu precisa sê-lo, pois há aqueles que nos acariciam com delicadeza, e/ou que nos protegem sutil ou duramente, os necessários. Importa observá-los e experimentá-los com objetividade (se flexíveis, rígidos, leves, pesados, porosos, densos), dar testemunho de seus domínios, calcular seus impactos. Suspeito dos véus. Não se pode confundir energia com agressividade. As forças materiais duras nos rodeiam, nos ameaçam e nos fazem viver, às vezes nos abrigam (idem, 2001: 111). O rasgo convive com o véu e a dobra.

Imperam as carapaças. Há cárceres. Mas se nada se constrói, nem se faz, nem se inventa, senão na paz relativa, em um pequeno reduto de paz local rara, mantido no meio da devastação universal produzida pela guerra perpétua, para se ter espaço, por menor que seja, pode ser necessário guardar um pouco do animal, ser feroz e não construir. Se a guerra é a mãe dos bichos (Serres, 2001: 70) talvez sejam os homens os pais da dita. Quem foi mesmo que deu esse nome a ela? Os bichos são uma cunha no mundo, abrem o ângulo entre o dizer e o dado (2001: 93). Apenas nós dizemos guerra. Dizer pode não ser fazer, mas há uma promessa ou recordação aí.

Rasgar também é coisa do infinito e do tempo, como eles, separa o descontínuo do contínuo em direção ao vazio, não como as mãos que desatam os nós dos fios entrelaçados do espaço, com o intuito de analisálos. Rasgar ignora o nó, desatar Ihe presta deferência. Desatar e rasgar são

2 Sobre o possível no Glossário de termos leibnizianos, 2015.

Revista do Programa de Pós-graduação em Arte da Un V.15, no1/janeiro-junho de 2016 
reversíveis até certo ponto, mas enquanto no primeiro refaz-se a trama linha por linha e aperta-se os nós, no segundo é preciso reconstituir as fibras, cerzir ou remendar.

O nó:

Inserção ou meio.

(...) situação "entre"...

(...) uma sequência alinhada sobre um segmento reto que separa os grãos,

ou povoa os espaços onde ambos estão inseridos ...

(...) um espaço-entre.

(...) no discreto (...), na continuidade, mais no primeiro do que no segundo

(...) O separado fará um nó melhor do que o inseparável? (Serres, 2001: 73-74)

Nó não é rasgo: o entre no rasgo não é o caminho de um lado ao outro, porque não se trata de um entre dois mundos. 0 entre é a estrutura rígida, uma carapaça desse mesmo mundo. Há variação de refinamento do entre: da pele - nosso suposto entre sutil, aquilo mesmo que somos, tecidos em dobras - às paredes, estradas, barragens - longe da delicadeza da pele, são obtusidades que deformam o espaço, se estabelecem duramente entre as paisagens. O espaço-entre está esgotado de inúmeros caminhos já tramados, e por ser ele mesmo traço que esquadrinha, é invariante, uma infinitude de caminhos que seguem em todas as direções possíveis comportadas num sistema. 0 espaço-nó é cheio de regras locais. 0 nó povoa os espaços (Serres, 2001: 73). O nó nos amarra (2001: 74). O rasgo sugere, em certa medida, o dilaceramento do entre, como ação local. Se é preciso imaginar dobraduras, invaginações, situações extraordinariamente complexas que generalizam a prática e a noção de nó em todas as dimensões imagináveis (2001: 75), rasgar abre caminho para o inimaginável, sem perder contato com o sistema enredado que antes isolava o espaço. A ação de rasgar não é revolucionária pois não pressupõe-se como resistência, direciona-se ao atravessamento dos limites das estruturas resistentes. Não é uma relação entre forças passivas, considera a resistência dos materiais não para variar as texturas, mas para 
romper ou dilacerá-las, no sentido contrário da dobra, mas considerando esta última como uma possibilidade.

Rasgar deixa a fragilidade exposta, evidencia apenas o que já se apresenta. Instabilidade à beira do rompimento, como catar cacos de louça fina com as mãos limpas. Persistência precária, parcela de eternidade. A fragilidade não precisa ser necessariamente franzina, debilitada, sem ânimo ou pouco resistente, mas é bem possível que caia em falta e seja leviana, ainda que acompanhada de certa solidez e potencialidade de rasgar. Assim como são os diamantes, duros. Capazes de riscar qualquer outro mineral ou substância, exceto o igual a si. Assim como são os diamantes, frágeis. Podem ser facilmente fragmentados sob a ação de um choque, rompem sem aviso prévio. Assim como são os diamantes, gerados sob altas pressões factíveis apenas no interior do planeta. Mas das altas pressões podem surgir diamantes de sangue ${ }^{3}$ de corpos escravizados; diferentes dos diamantes, riscamos nossos iguais em todas as direções. Fragilidade, fratura e deformação dos corpos. Deformar-se, sair da forma.

Frente às assombrosas imagens de caixas-pretas, casca e invólucro, alguém pergunta: podemos quebrar os círculos e fugir? É um muro compacto, um muro duro, liso e intransponível. Lei. Limiar. Aquele que observa busca um olhar, uma ameia, fissura ou lacuna. Há outro que sonha, no sonho recorta uma falsa janela no muro (Serres, 2001: 91).

O joão-de-barro constrói todos os anos seu ninho em espiral, mineral dobrado para proteger os ovos, e o abandona tão logo o filhote possa voar. Como nós, edifica caixas refinadas ao redor de seu corpo, mas logo deixa a edificação engenhosamente construída com terra e saliva. Celeida Tostes ${ }^{4}$, praticante dos atravessamentos do espaço - muros que vazam prisões (O Muro, 1982), penetrações no ventre da terra (Passagem, 1979)

\footnotetext{
3 Diamantes extraídos geralmente por mão de obra escrava para financiar guerras.

4 O livro Celeida Tostes (2014), organizado por Raquel Silva e Marcus de Lontra Costa, apresenta uma vasta documentação sobre a obra da artista e serve como principal fonte de seus textos e imagens para este trabalho. 
-, conheceu bem as casas dos pássaros. Estudou minuciosamente a composição e o processo construtivo, tentou reproduzi-los com os seres humanos, mas a mistura resultou fraca. Para quem sabe voar não bastam paredes sólidas. Sem apego ou culpa a ave abandona a caixa. Em Passagem (1979), Celeida Tostes, despojada de si, cobre seu corpo de barro para adentrar a terra. Diz ter perdido o sentido de tempo. Mineral, animal, vegetal, ela não soube dizer o que foi, nem onde estava, nem por onde passava. Espaço. Sem história. O escuro, os sons, a dor se confundiam (Tostes, 1979 apud Silva; Costa, 2014). Transmutada, a artista rasga a capa de barro que a envolve, volta, abandona-se. Ela saiu e voltou. O Muro (1982) tornou-se um rasgo nas estruturas rígidas sociais, um vetor de permeabilidade e transposição de obstáculos tão vigoroso que não pôde ser realizado sob pena de produzir vazios imensos impossíveis de sutura. A artista rasga os espaços, produz estruturas que rasgam, abre caminhos, mergulha no mineral, constrói efêmero. Mistura barro, bosta, capim, cuspe, palha para construir como o joão-de-barro uma casa para deixar. Tijolos cozidos perpetuam. Se destruídos voltam à terra.

A caixa que protege fragiliza. 


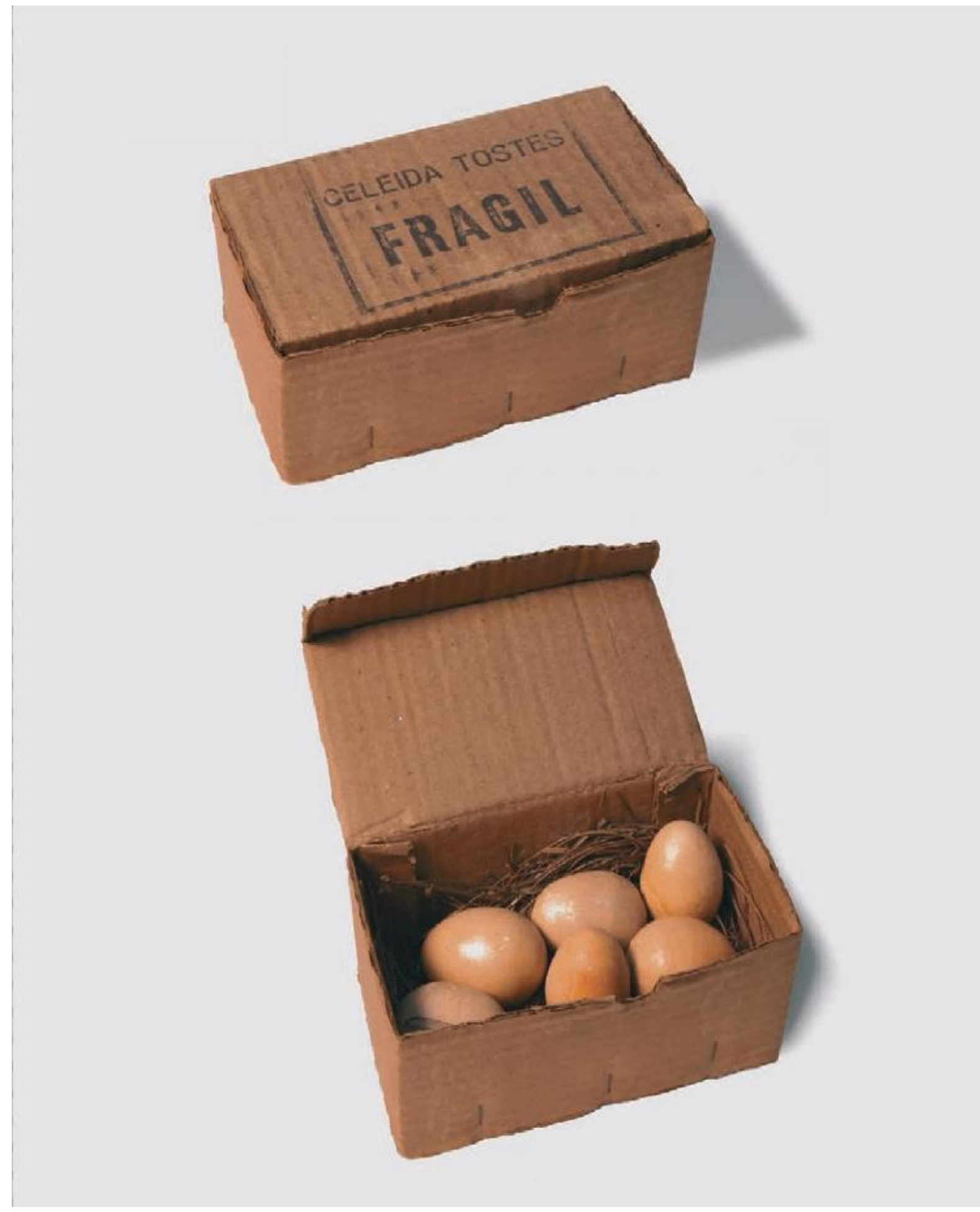

Fig.1. Celeida Tostes [p. 127], Sem título, série Ninhos, s.d., cerâmica, palha e cartão, 8,3 x 18,3 cm; coleção MAM RJ. Doação Esther Chamma de Carlos . Foto: Leonardo Ramadinha. Fonte: (Silva; Costa, 2014, p. 127).

Próxima Fig.: 2. Claudia Washington. Caixas de cacos, 2015. 700 cacos de louça em caixas de papelão, dimensões variáveis. Arquivo pessoal 


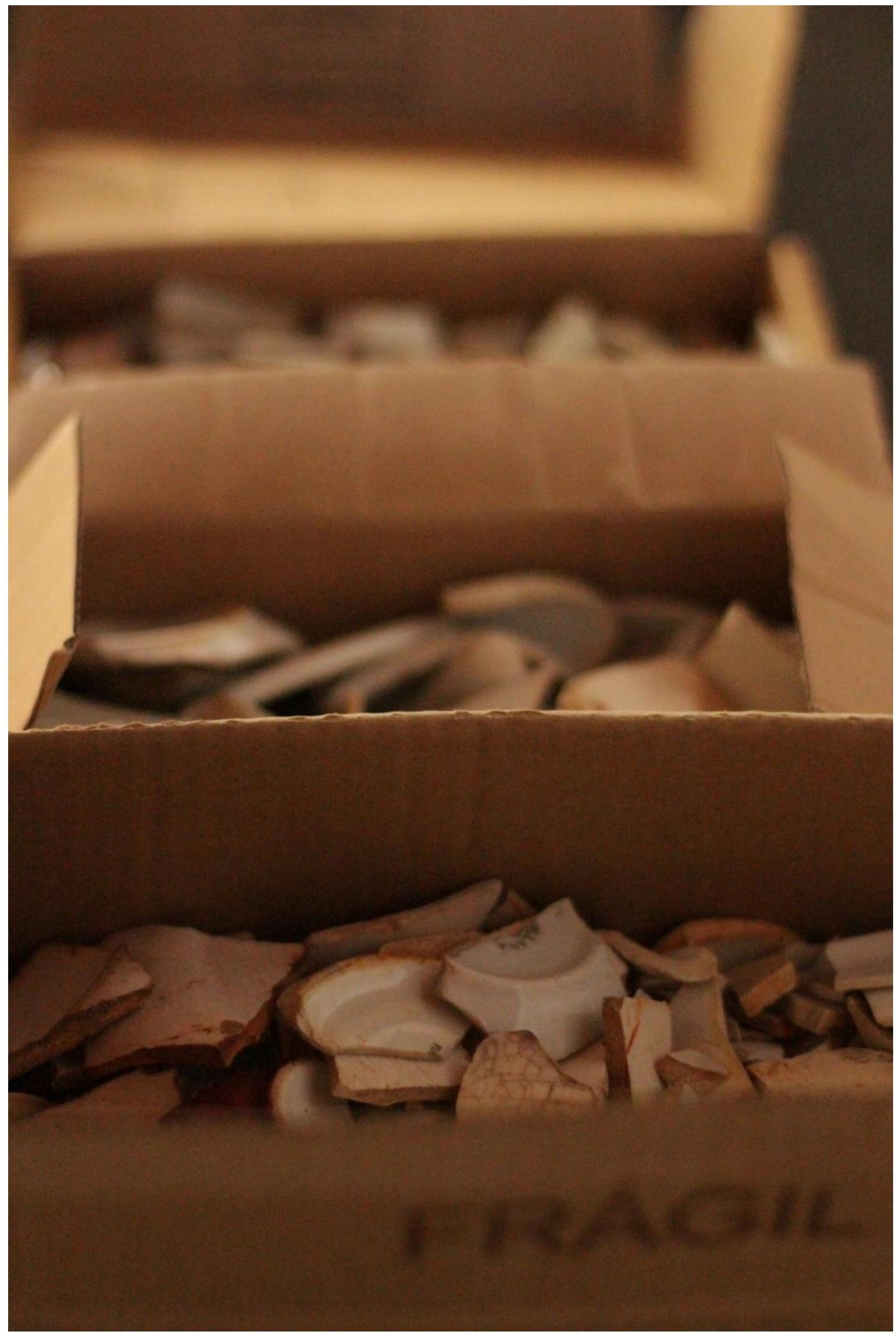

Revista do Programa de Pós-graduação em Arte da UnB V.15, nº1/janeiro-junho de 2016

Brasilia
SSN-1518-5494 
Frágil, a casca do ovo é o invólucro perfeito da gema dourada, mesmo assim, forças externas podem destruí-la facilmente. As durezas se encontram. $\mathrm{O}$ bruto. A materialidade do mundo fere a pele, trespassa-a com varas, arranha-a nas rochas, estilhaça-a nas guerras. Tão tirana quanto a dureza é a doçura. Ela torna cativos nossos sentidos sutis. É informação. A palavra vento não derruba (Serres, 2001: 110) mas pode controlar os corpos. $\mathrm{O}$ que distingue o duro do doce é a materialidade do invólucromeio? Simultaneamente prisão e passagem. Nossas cidades, crisálidas de imundície, alimentam-se do doce e do duro. Não somos suficientemente ricos para o total isolamento do duro. Nosso doce, demasiado, não satisfaz a voracidade dos múltiplos paladares. $O$ fedor nas valetas persiste. Os doentes, em multidões, esperam dilacerados nos corredores. As estradas esburacadas produzem mais e mais corpos em pedaços. Nossas catástrofes ambientais brincam perversamente com as misturas, chumbo, manganês e arsênio ${ }^{5}$ em níveis acima do permitido, há metais pesados fluindo pelo Rio Doce, elas revertem instantaneamente o Doce em duro. A precariedade de nosso entorno 0 tensiona o bastante para desejarmos rasgar 0 ninho de plástico, de chumbo, de espelhos, de palavras, e alçarmos voo.

A morte é uma saída do mundo caixa-preta, mas antes dela e por nada saber sobre ela, atestados os limites, o corpo quer mover, pelos caminhos demarcados ou por outros. Mover-se na caixa-preta de duas faces: lugar, espaço, volume, variedade enfim onde as energias transitam de uma escala a outra. Caixa-preta doce para as energias altas, caixa dura para as muito baixas (idem, 2001: 126). O perigo está no contato com as energias altas, são forças naturais que nos devastam. Estamos imersos nas altas energias. Precisamos nos proteger, portanto: caixa-preta doce. Já para as energias muito baixas, língua, signos, códigos, o acesso só se faz pelo exercício

\footnotetext{
${ }^{5}$ Segundo relatório parcial de pesquisadores da Faculdade de Ceilândia (FCE - UnB) e do Grupo Independente de Avaliação do Impacto Ambiental, Ceilândia, dezembro de 2015. 
árduo, é preciso zelar por elas: caixas-pretas duras. 0 doce para o duro e o duro para o doce. O somatório frágil dos não integráveis (2001: 135).

Não penso que haja acordo entre nosso corpo e as coisas. As regras de tal acordo seriam apenas nossas, não há acordo com a rocha. Estabelecemos acordos com os animais, mesmo assim, imaginamos que as regras sejam nossas, se bem que nem sempre são. Nosso corpo entra em desacordo, aí sim, prestes a se romper, a sensação condiciona-lhe a vida: o acordo exige uma mudança de escala, das baixas às altas (ibidem, 2001: 126).

Dilacerar é analisar: A abstração recorta o corpo que sente, suprime 0 gosto, o olfato e o tato, conserva apenas a vista e o ouvido, intuição e entendimento. Abstrair significa menos sair do corpo do que o rasgar em pedaços: análise (Serres, 2001: 21).

Recordo estarrecida o Tiradentes Esquartejado (1893) de Pedro Américo nas primeiras lições de História em minha escola primária - chamada de 31 de Março, seu nome fazia deferência ao golpe militar de 1964. De qualquer forma o que me chocava, absorta do contexto, era o corpo em pedaços estampados em cores no livro, a coxa enfiada em estacas, a cabeça no alto parecendo avistar algo no horizonte, um herói nacional em pedaços, um mito. Depois fiquei sabendo que não era bem assim, e tinha ainda Canudos, Contestado, Paraguai, todas as lutas cruentas e cabeças cangaceiras. Mas a experiência quase diária de procurar minúcias sangrentas naquela imagem retorna agora em mim, talvez esteja desde então no meu corpo sabedor do que procura.

A Experiência nº 2 (1931) de Flávio de Carvalho também reverbera nesse lugar. Após uma perseguição pelas ruas, acuado no vão entre prédios, a mente de Flávio de Carvalho finaliza sua fuga da multidão enfurecida em 
diasparagmos ${ }^{6}$. Imagina braços, dedos e mãos, surgindo de uma multidão ausente, que o rompiam aos poucos, sente alguém enfiar o dedo num dos seus olhos e puxar a pele rasgando (Carvalho, 2001: 43). 0 ato, por ele medido, de penetrar na multidão, a seu tempo, tornou-se incontrolável, os sentidos foram alterados. Em seu livro Experiência $n .^{\circ}$ 2: realizada sobre uma procissão de Corpus-Christi: uma possivel teoria e uma experiência, publicado em 1931, Flávio de Carvalho descreve minuciosamente sua experimentação e também faz uma análise psicológica do ocorrido a partir de um método arqueológico que conserva os vazios entre a ação e a escrita. No capítulo Análise, expõe os mecanismos, fases e séries da procissão (multidão que por fim o persegue). Atribui uma certa ordem de laços a ela, relaciona maleabilidade, persistência e determinismo aos seus componentes. Nela, forças agressivas se anulam. Seu método esfacela a multidão compacta através de diagramas triádicos que compõem pares antitéticos como laços afetivos. Descreve equações. Parametriza. Disseca o mito do pai ancestral em religião e pátria, fetichismo e totemismo.

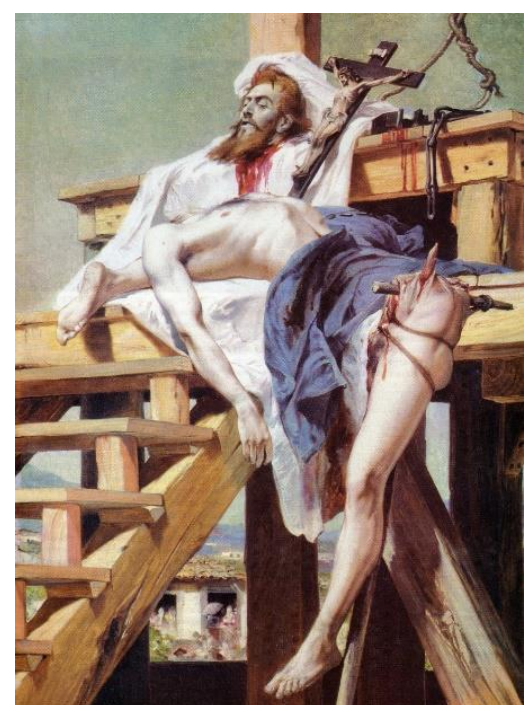

Fig.3. Pedro Américo, Tiradentes Esquartejado, 1893. Óleo sobre tela, 270 x $165 \mathrm{~cm}$. Museu Mariano Procópio, Juiz de Fora, Brasil. Fonte:

Fonte:<https://blogdaines.files.wordpress.com/2009/12/tiradentes-supliciado-de-pedroamerico.jpg>. Acesso em: 20 dez. 2015.

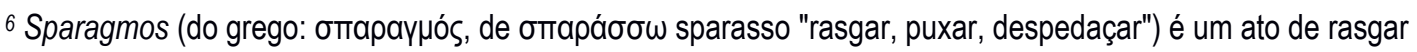
ou desconfigurar, geralmente em um contexto dionisíaco (tradução nossa). Disponível em: https://en.wikipedia.org/wiki/Sparagmos . Acesso em: nov 2015. 
Frente a um panorama arqueológico, por ele mesmo apontado como ilusório, pesca emoções que compõem um conjunto enigmático desconexo. O processo psicológico funciona como uma gaze contínua, uma base hipotética que une os pedaços sem encher os vazios. Neste caso, a análise é uma amarra imprecisa. O diasparagmos é o desejo sem fim da humanidade face à sugestibilidade do mundo objetivo que cria no homem um potencial, um início de fantasia capaz de desarranjar o organizado (Carvalho, 2001: 140). A proposta de Flávio de Carvalho, de juntar ação e dizer, não pretende substituir a coisa pela palavra (Serres, 2001: 130), é concebida sob influências deformadoras, conservando os vazios dos rasgos da ação.

Eurídice e Orfeu foram rasgados radicalmente em pedaços, e dispersos pelos Infernos ou levados pela correnteza. Eles provaram do diasparagmos tão frequente nos mitos (idem, 2001: 132). Ela, em sua segunda morte, é desmembrada pelas forças dos Infernos e ele rasgado pelas mulheres. 0 diasparagmos equivale à análise, assim, diz o contrário de construir ou de ligar (2001: 133).

Para Flávio de Carvalho a análise é uma gaze contínua, atadura para os rasgos, ela parece funcionar no avesso do exemplo acima. Nos dois casos - análise gaze contínua e análise diasparagmos - uma localidade singular se estabelece, onde os pedaços se agrupam e onde a unidade se dilacera. A violência se apresenta no furor da multidão, tanto nos jovens da procissão quanto nas mulheres que rasgaram Orfeu, nos gritos de - Lincha! e na balbúrdia feminina. A exemplo da análise, a violência do som também é ambivalente: se o grito agride, o silêncio também pode fazê-lo.

\section{Silêncio}

Se qualquer matéria vibra e conduz o som, sobretudo a carne (ibidem, 2001: 42), é nela que se pode sentir os desgostos do silêncio imposto. Um 
pesar generalizado quando se trata de uma cidade inteira. Até aquele momento, durante todo o tempo de existência daquela cidade, e antes dela, se ouvia o choque feroz das águas de um imenso rio nas rochas magmáticas do leito. $\mathrm{O}$ som, aos poucos, foi perdendo força até que calou definitivamente. Consternados os ouvidos estão, desde então, para os velhos do lugar. A voz de Tupã (guia dos nômades) ou Sete Quedas (conjunto natural de quatorze cachoeiras em meio ao Rio Paraná) foi atingida pelo alagamento causado pelo fechamento das comportas da barragem da Usina de Itaipu, em 1982, e desde então submerge num gigantesco lago. A inundação mergulhou os corpos em silêncio profundo, antes imersos na ondulação incessante do som das quedas. Aquele que é maturado com o rumor das águas nas rochas não conhece senão esse embalar. Tentem silenciar o mar. Imaginem estar num quarto em penumbra tranquila: subitamente o espaço é inundado por luzes intensas. É possível enxergar as paredes? Os rostos são reconhecíveis? O que há entre um vão e outro?

Ana7:

O rio Paraná era, antes das Quedas, o que ele é hoje, essa imensidão, até as quedas. Aí afunilava e caía num canal, que era o Canalão do Rio Paraná, um cânion. 0 Rio Paraná só voltava a ser navegável 60 quilômetros abaixo, onde foi construído o Porto Mendes. A água das Quedas, era a maior catarata do mundo em volume de água, depois das Quedas era de uma fúria tão assustadora. Imagina tudo isso caindo num cânion de 100 metros. 0 que me impressionou sempre foi o Canalão, a grande violência dele. (Entrevista com Ana, Trânsito à Margem do Lago, 2010)

Silenciada também foi a promessa de construção de uma outra usina hidrelétrica nas proximidades da cidade. Essa que geraria riquezas, servindo como moeda de troca quando da negociação com a população local. A usina nunca foi construída. O emudecimento forçado dessa cidade foi acentuado pelo impedimento de manifestações públicas, instituído pela ditadura da época. Múltiplos silenciamentos.

\footnotetext{
${ }^{7}$ Ana e Margarida, citada mais adiante no texto, são moradoras de Guaíra desde antes da inundação do Rio Paraná. 
Um silêncio diferente daquele que constrói o ninho, o habitat da sensação (Serres, 2001: 134). O silêncio cela. Corte radical do frágil equilíbrio do corpo no espaço. Pedaço arrancado, dilaceramento, subtração. Silêncio que rasga. Princípio do (des)concerto taciturno das grandes intervenções da engenharia. Aplausos.

\section{Margarida:}

Fazia parte do evento mostrar a iluminação da barragem à noite... Tudo apagado. Apagaram as luzes do local onde nós estávamos para poder acender as luzes lá. Elas vão se acendendo, algumas luzes bem fraquinhas e vai aumentando o brilho. E daí a gente vê a beleza da construção, do tamanho. Para nós, aquilo começa a doer muito... e quando as luzes começaram a ficar mais fortes... eu olho de lado assim, para ver... estávamos todos chorando, chorando pela mesma causa... porque quando vimos todo mundo em silêncio vendo aquela beleza, nós pensamos no que tínhamos perdido, o que está adormecido embaixo d'água. ${ }^{8}$ (Entrevista com Margarida, Trânsito à Margem do Lago, 2010)

Com a morte da música, calada a fúria das águas nas rochas, mineral e mineral, o lugar se enche de slogans, caixas intermináveis se desdobram. A audição mergulha no silêncio e na surdez (Serres, 2001: 137). Resta a lembrança da sala de teatro que abria suas portas por onde via-se as quedas e ouvia-se-lhe os urros, e também a esperança fantástica do rompimento da represa e o retorno do monstro adormecido.

Que chamado, grito, fogo, animado, móvel, intenso agudo, tem poder de lançar um fluxo que derruba os obstáculos e é depurado pelos filtros deles? (idem, 2001: 142).

Uma teoria: dispender nossa energia criativa em rasgar véus, e cuidar da pele, amar a pele. Ensolará-la. Não num corpo de ciência, mas num corpo sem medidas, ainda que ame por entre barreiras. Sentir pavor e fugir é uma boa escolha, sentir pavor e rasgar a seu tempo cada caixa, também. 0 corpo já tão pesado de véus, capas, carapaças, por ele mesmo erguidas

\footnotetext{
${ }^{8}$ Margarida descrevia uma visita feita às instalações da Usina Hidrelétrica de Itaipu.

Revista do Programa de Pós-graduação em Arte da Un V.15, no1/janeiro-junho de 2016 
ou infringidas pelos sistemas humanos, sabe construir paredes quando precisa e também ampliar seu espaço, não se espera mais que o exterior ceda lugar, nunca se esperou, nem se parte simplesmente em fuga, construímos, destruímos, desestabilizamos, no sentido da catástrofe e contra ela.

\section{Idade do Chumbo}

Desequilíbrio. No caminho ondulante para uma pequena cidade, num pobre vale de uma região montanhosa rica em minérios, as placas de trânsito alertam que por ali pedras rolam dos morros sobre os carros. A contaminação sem cheiro e sem cor, nas águas, no solo, nas peles, ovos, sumos e bebês, atravessa décadas, desde as primeiras mineradoras.

$\mathrm{Na}$ entrada da cidade se vê o reluzente mega maquinário da nova fábrica de cimento. No caminho para uma mina abandonada letreiros suplicam: Não jogue lixo, nos ajude a cuidar da natureza. Mais à frente encontramos a boca aberta da mina na beira da estrada, na grade violada 0 aviso: Proibida a entrada. Mais ao lado, num portão de telas rasgadas pelo tempo e por animais de quantos pés se queira, uma tabuleta adverte: PERIGO ULTRAPASSE. Alguém apostou no sarcasmo e suprimiu o negativo. $\mathrm{Na}$ Caverna de Platão invertida o excesso de luz cega. 0 que foi produzido com o chumbo dessa mina: proteção contra a radiação, baterias, soldadura, aditivo da gasolina, munições? Como rasgar a crosta de meu olhar indiferente?

O chumbo cintila na superfície e inscreve ali seu estar invisível, sua chocante não aparência. A confusão se faz entre minerais, entre minerais e gazes atmosféricos, entre minerais e carne. Da metalurgia das ligas (Serres, 2001: 163) surgem abóboras, galinhas, vacas, homens, mulheres e crianças de chumbo. No túnel, a umidade, o frio e o temor não permitem a estada, o tempo estagnado nos permite ouvir o caminho do pingo d'água 
do teto ao chão. E lá vai o ônibus escolar levantando poeira tóxica. PLUMBUM! As forças atômicas da terra expostas a céu aberto. Quem, ainda em vida, ousou fender o frágil véu entre nós e os subterrâneos? Não há cerzido que possa ser feito a tempo. Venham bruxas e alquimistas refundir a rocha dispersa pelos ares ou rasgue-se a lei que permite cimentar pulmões.

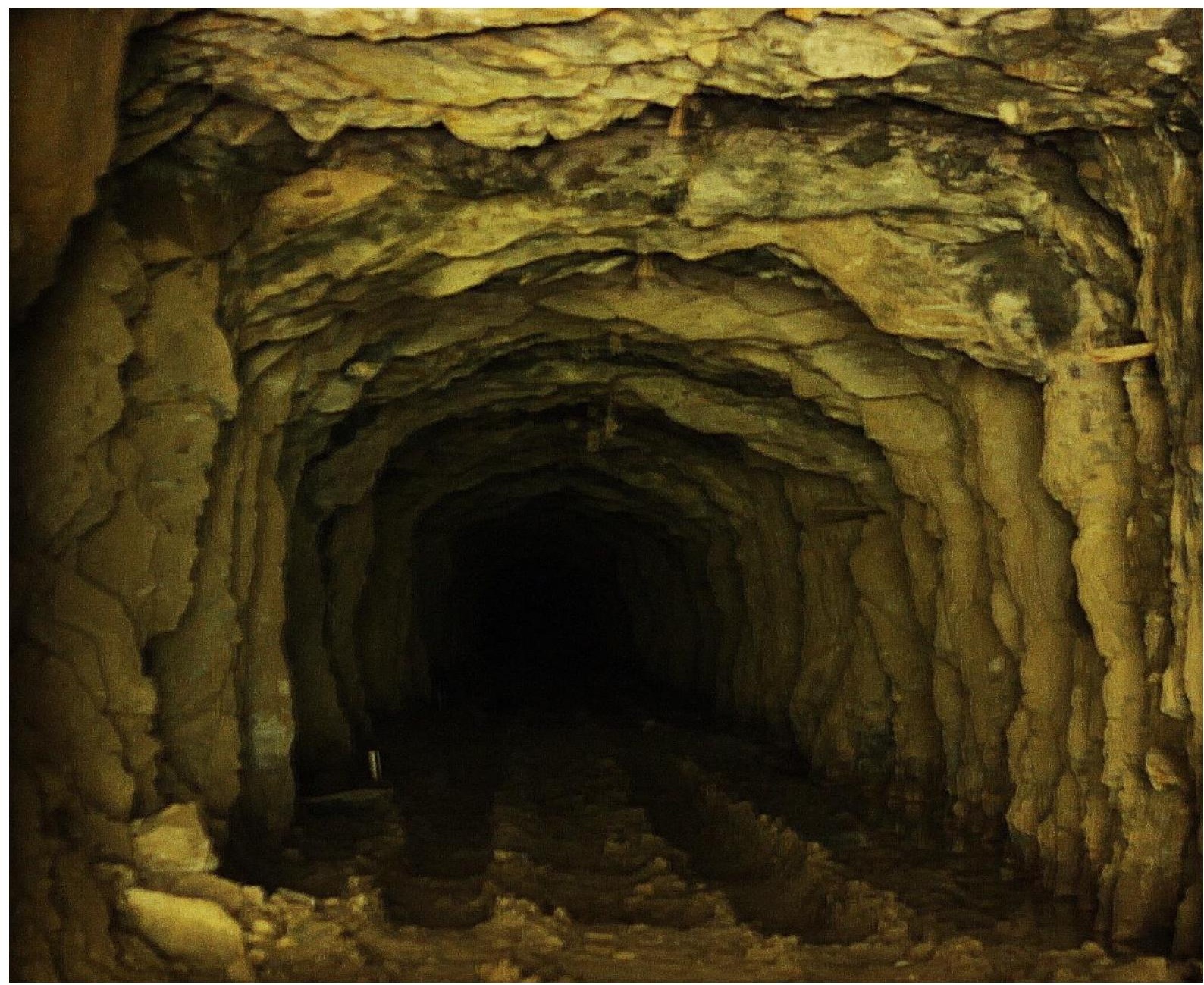

Fig.4. Claudia Washington,PLUMBUM! Boca de Mina, 2015-16. Adrianópolis, Brasil. Fotografia, dimensões variáveis. Arquivo pessoal. 


\section{Tempo e poder}

O tempo do rasgar é um tempo exato, calculável, mas seu espaço gera o indefinido. Se é possível encontrar ou cavar lugares onde o tempo congela, se um obstáculo pode detê-lo, se ele percola (idem, 2001: 181), também podemos rasgar os meios, lugares e obstáculos, forjar outro tempo distinto da clausura. A aparente lentidão das placas gigantes que se deslocam, sob a terra (2001: 207) ilude aquele que pensa o tempo como seu tempo, na contagem de milímetros e milênios. Unidades de medida humana. Do mesmo modo que podemos pensar que o sol não se extingue, que é fonte universal e infinita (2001: 217) - pois assim ele é para nossos sentidos, mesmo que saibamos que haverá um fim - o tempo da Terra não é adjetivável, nem a velocidade de seus atos. Pois, construímos finito, durante nossa vida breve, e mais finito ainda porquanto construímos com 0 já construído (2001: 225). A fugacidade dessa existência e uma ânsia por não esgotar nosso tempo todo dia nos atos (2001: 181), nos leva a construir obstruções para acessar potência (represas, pedreiras).

As obstruções põem o potencial em nosso poder. Em poder de quem? Sabemos que as represas e pedreiras conservam potencial, mas, quem desfruta dele? Quem constrói o espaço o domina? As mãos que levantam as obstruções raramente empoderam-se com o potencial gerado. Essas reservas asseguram lugares de privilégio. Filtros que controlam fluxos. Uma logística dos estoques não se compara ao atravessamento de barreiras. Para romper obstáculos é necessário um esforço extremo. Fazer um filho não é um capricho do corpo, só uma vontade sem fim para suportar um parto, isto é, rasgar. Sair de caixas ou úteros requer obstinação. A tentativa é de nos manter imóveis. A escola faz bem isso, reproduz pátios quadrados no meio do mato, aonde ainda temos mato. E é obvio o treinamento ao túmulo, à submissão social. Ali também se ergue a prisão da palavra. A escola do consumo é um monstro tão perverso quanto a escola da miséria. Ambas desertificam o campo frutífero entre palavras e sentidos. Para elas a palavra é metal, ouro (acumulação de vazio) de uma e gradil da outra. 
Não formam adultos contentes, nem poetas, nem sábios, nem filósofos livres, porque, com eles, tudo pode acontecer (Serres, 2001: 195), e essa não seria a meta.

O empirismo supõe o mundo belo e infinito em seus tesouros (idem, 2001, 218), no meu mundo o fim esteve sempre muito próximo. Esse filho da guerra (2001: 197), e para seguir a linhagem, irmão dos bichos, se apresenta no vazio que as frases não preenchem. Vazio além da pobreza de vocabulário, vazio que se revela em toque, em pele, em tato, ações sem par. A abundância, profusão eterna de tudo, desmonta a raridade e as contrapartidas. Em arte essas duas produzem aberrações comerciais e burocráticas, discursam sobre grandes nomes e cobram caro o uso de seus museus degenerados. A raridade e a contrapartida cooperam com 0 estabelecimento de barreiras intransponíveis, barreiras materiais e de linguagem que definem a quem se direciona a potência da fúria natural, da energia dura, reservada pelas outras barreiras de contenção (2001: 222). Aquelas construídas com mão de obra barata. 0 espaço se apresenta dividido entre informados sábios saciados e moribundos nus famintos. Os últimos erram ao redor dos primeiros isolados por barreiras, nisto define-se centro e periferia, sendo o centro o lugar da lei, da economia, da ciência. 0 espaço se dividiria mesmo em duas áreas? Os que estão fora teriam mesmo que entrar? Querem entrar? E se fossemos informados moribundos, sábios nus, famintos saciados? Outros espaços surgiriam entre eles, misturados.

Um estômago vazio, pés descalços, sem telhado, sem roupa, sem casa... de privações estamos cheios, rasgue-se o véu da miséria. Caminhamos para a feiura pela rigidez? (idem, 2001: 199) Rasgue-se a máscara ritidoplástica. Mas tudo tem um preço, é a lei da economia. Quem inventa o espaço é o seu senhor. A gratuidade do sensível, que tem no empirismo um amigo (2001: 223), é também espaço de poder a ser retomado, reencontrado sob os véus de sabores idênticos aos naturais, sob as 
máscaras de mil emplastros iguais, sob tecidos e roupas anunciando seus nomes próprios... por isso exercitar o rasgo para sair do mesmo. Habitar a casa própria de seu corpo, deixar a prisão (2001: 229). Enterrados sob camadas sem fim de objetos e informações, pode ser preciso o vazio para surgir o mundo.

Rasgar é o que posso fazer, com minhas mãos, com meus dentes e unhas certamente, talvez com todo o resto do corpo e, até mesmo, com a palavra. Rasgar as estruturas rígidas da minha ignorância, preconceitos, crenças. Sutil, frágil, feroz. Furar a estátua. Livrar-me da concha de palavras que (...) arrancam a pele (Serres, 2001: 203). A estética prova o improvável (2001: 226). A arte interminável, inintegrável, dilacerante, engendra espaços para o movimento, para o reencontro das peles, dos cheiros invulgares das coisas, estranhos sabores, caminhos excêntricos, extraordinárias visões, insólitas paisagens.

\section{Referências}

CARVALHO, Flávio. Experiência $n .^{\circ}$ 2: realizada sobre uma procissão de CorpusChristi: uma possível teoria e uma experiência. Rio de Janeiro: Nau, 2001.

CAUQUELIN, Anne. Arte contemporânea: uma introdução. São Paulo: Martins Fontes, 2005.

DELEUZE, Gilles. A dobra: Leibniz e o barroco. Tradução: Luiz B. L. Orlandi. $2^{\text {a }}$ edição. São Paulo: Papirus, 2000.

Glossário de termos leibinizianos. Disponível em: <http://www.leibnizbrasil.pro.br/leibniz-glossario.htm>. Acesso em: 20 dez. 2015.

MEDEIROS, Maria Beatriz de. Aisthesis: estética, educação e comunidades. Chapecó: Argos, 2005.

RAMOS, Pedro Paulo. Secom UnB. Análise realizada no campus Ceilândia detecta níveis de arsênio, manganês e chumbo acima do permitido. Meio ambiente, dez. de 2015.2 Disponível em: $<$ http://www.unb.br/noticias/unbagencia/unbagencia.php?id=9777\#>. Acesso em: 28 dez. 2015.

SERRES, Michel. Os cinco sentidos: filosofia dos corpos misturados - 1. Rio de Janeiro: Bertrand Brasil, 2001.

SANTOS, Milton. Da totalidade ao lugar. São Paulo: Edusp, 2005.

SILVA, Raquel; COSTA, Marcus de Lontra (Orgs.). Celeida Tostes. Rio de Janeiro: Memória Visual, 2014 
SPARAGMOS. In: Wikipedia: the free encyclopedia. Disponivel em: https://en.wikipedia.org/wiki/Sparagmos. Acesso em: nov 2015.

SVIZZERO, Darcy Pedro. As múltiplas facetas do diamante. Revista USP, São Paulo, n.71, p. 52-69, setembro/novembro 2006.

Artigo recebido em fevereiro de 2016. Aprovado em abril de 2016 